UNIVERSITY

OF DEBRECEN

FACULTY OF

Health

NYÍREGYHÁZA

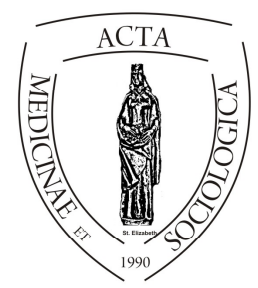

ACTA

MedSoc

Volume 7.

2016

\title{
A megváltozott munkaképességü személyek nyílt munkaerőpiacra történő re-integrálhatóságának vizsgálata
}

\section{Testing disabled people integrate to the open labor market}

\author{
Botfalusi Klaudia
}

EuroRaptor Tanácsadó és Pályázatíró Kft.

\begin{abstract}
Ever closer cooperation with the European Union, new vision and needs of the development of the social economy comes to call special care to disadvantaged groups increasingly. The social integration of persons with disabilities to promote the possibility of very important not only gave the rehabilitation of health facilities to take stock, review the full investigation is needed. In itself it is a huge step forward, if a society does not treat this layer aversion and attitude able to realize the full inclusion. However, if we want to achieve complete integration, it is very important to examine possibilities for employment of persons with disabilities. Today, I believe that can be treated as a fact that the active participation of the changed working abilities, persons with disabilities in social life, especially in the open labor market employment can be achieved.
\end{abstract}

Keywords: persons with disabilities, open labor market, social integration

DOI: $10.19055 / \mathrm{ams} .2016 .7 / 22-23 / 7$ 


\begin{abstract}
Absztrakt. Az egyre szorosabb Európai Unióval való együttmüködés az újszerü látásmód és a szociális gazdaság fejlődésének igénye egyre inkább életre hívja a hátrányos helyzetű csoportokkal való fokozott törődést. A fogyatékos személyek társadalmi integrációjának elősegítésének lehetőségénél nagyon fontos nem csupán az egészségügyi rehabilitációjuk adta lehetőségeket számba venni, hanem teljes áttekintő vizsgálatra van szükségünk. Önmagában az is hatalmas elörelépés, ha egy társadalom nem averzióval kezeli ezt a réteget és szemléletében képes a teljes befogadás megvalósítására. Azonban, ha valós, teljes integrációt szeretnénk elérni nagyon fontos megvizsgálnunk a fogyatékos személyek munkavállalásának lehetőségeit. Napjainkban úgy vélem tényként kezelhetjük, hogy a megváltozott munkaképességü, fogyatékossággal élő személyek társadalmi életben való aktív részvétele elsősorban a nyílt munkaerőpiacon való foglalkoztatással érhető el.
\end{abstract}

Kulcsszavak: megváltozott munkaképesség, nyílt munkaerőpiac, társadalmi reintegráció

\title{
Bevezetés
}

A megváltozott munkaképességü személyek nyílt munkaerő piaci integrációjának igénye szülte többek között a TÁMOP-5.3.8. A3-13/1-212-0009 azonosító számú projektet, mely az Európai Unió támogatásával és az európai szociális alap társfinanszírozásával valósult meg. A pályázat célja a megváltozott munkaképességü, foglalkoztatási rehabilitációban részesülő személyek munkaerö-piaci integrációjának elősegítése. A projekt a nyílt munkaerő-piacra történő kihelyezés hatékonyságának növelése érdekében, speciális kompetencia- és készségfejlesztést, valamint képzési lehetőségeket, mentori tevékenységet, foglalkoztatási rehabilitációs szolgáltatások nyújtását biztosítja a célcsoporttagok számára. Cél, hogy a megváltozott munkaképességüek aktivitási és foglalkoztatási esélyei javuljanak, képzések, szakmai és informatikai fejlesztések, munkaerő-piaci szolgáltatások biztosításával.

Írásomban célom bemutatni, hogy a pályázatban részt vett megváltozott munkaképességü személyek nagyobb eséllyel indulnak a tréning során megszerzett kompetenciákkal, tudásanyaggal a nyílt munkaeröpiacon. Mérhetővé szeretném tenni, hogy a pályázat milyen pozitív hatásokat gyakorolt a résztvevőkre. Különösen érdekel a pályázatban részt vett megváltozott munkaképességü emberek személyes tapasztalata mely mintaként szolgálhat a későbbiekben hasonló csoportok nyílt munkaerö-piaci elhelyezkedésének elősegítésében. Kíváncsi voltam arra a fejlődési mechanizmusra, melyen keresztül mentek a részt vevők a pályázat kezdetétől a végpontjáig arra ,hogy hogyan éli meg egy megváltozott munkaképességü személy azt, hogy újra visszaül az iskolapadba több év munkanélküliség vagy szegregált, „,védett” munkakörnyezetben eltöltött idő után. Sze- 
retnék rávilágítani azokra a pozitívumokra, melyek a kezdeti nehézségekhez képest végül minden résztvevő szemléletét és tudásanyagát gazdagították.

A fogyatékos személyek társadalmi integrációjának elősegítésének lehetőségénél nagyon fontos nem csupán az egészségügyi rehabilitációjuk adta lehetőségeket számba venni, teljes áttekintő vizsgálatra van szükségünk. Önmagában az is hatalmas előrelépés, ha egy társadalom nem averzióval kezeli ezt a réteget és szemléletében képes a teljes befogadás megvalósítására. Azonban ha valós, teljes integrációt szeretnénk elérni nagyon fontos megvizsgálnunk a fogyatékos személyek munkavállalásának lehetőségeit. Illetve az ezt elősegíteni kívánó támogató, képzési rendszereket. Fontos számba vennünk, hogy a fogyatékossággal élők eredményes munkaerö-piaci elhelyezkedésének érdekében milyen képzési stratégiák léteznek, illetve, hogy beszélhetünk-e tipikusan rájuk szabott képzési feltételekről.

Napjainkban úgy vélem tényként kezelhetjük, hogy a megváltozott munkaképességü, fogyatékossággal élő személyek társadalmi életben való aktív részvétele elsősorban a nyílt munkaerőpiacon való foglalkoztatással érhető el. Az Európai fogyatékos ügyi stratégia a 2007-2013-as évekre világosan rögzíti azt az alapelvet, miszerint a fogyatékossággal élő személyek nyílt munkaerő-piaci foglalkoztatása uniós fellépést és minden nemzettől elvárható erőfeszítéseket igényel. A 2010-2020 évekre irányadó új országos fogyatékos ügyi program pedig célul tüzi ki a fogyatékossággal élő személyek nyílt munkaerő-piaci munkavállalását akadályozó jogszabályi, szakmai, tárgyi követelmények felszámolását, a munkaadók és a fogyatékossággal élő munkavállalók érdekeltségének megteremtését. A változásoknak nemcsak a szakembereket kell gondolkodásbeli változásokra késztetniük, hanem a politikai döntéshozókat is. A paradigmaváltásnak mind egyéni, mind rendszerszinten meg kell történnie: konkrétan intézményi, szociálpolitikai és társadalmi szinten is. Ha ma még a nemzetközi gyakorlatban megjelenő eszközök a hazai rendszer számára távolinak és idegennek tünnek is, ezek megismerése, elemzése fontos részét kell, hogy képezzék a hazai változások folyamatának.

\section{Csökkent vagy megváltozott munkaképesség, fogyatékosság}

Az elmúlt évtizedekben a gyógypedagógiában és annak rokon tudományterületein egy sor olyan szemléletbeli változás zajlott le, amely jelentősen átformálta a fogyatékosságról és a fogyatékos személyekről alkotott képünket. Az utóbbi időszak egyik legjelentősebb változása a WHO 2001-ben megjelenő modellje a 
funkciók nemzetközi osztályozásáról. E modell alapján a fogyatékosság immár nem csak és nem elsősorban a betegségből fakadó állapot, hanem több tényező kölcsönhatásaként megjelenő elégtelen összhang az egyén készségei és képességei, a tőle elvárt teljesítmény és a környezeti lehetőségek között. Ez a szemléletbeli változás a szakemberek korábbi fogyatékossághoz füződő viszonyát alapjaiban változtatta meg, s ezzel együtt a gyógypedagógia, szociális munka feladatai is átértékelődtek. A megsegélyezett, ellátott ember személyét napjainkban felváltja a kliens szerepköre, a szolgáltatást igénybe vevő személy, aki maga dönt az életét érintő kérdésekben. (RUZSICS, 2014)

Fontos megkülönböztetnünk, két első hallásra nagyon hasonló, azonban jelentésében mégis eltérő fogalmat. Mégpedig azt, hogy mi is a különbség a munkavégzési és a munkavállalási képesség között!? A különbségek tisztázására Csoba 2009. és Farkané et al. 2011. is felhívja a figyelmet.

A munkaképesség adott tevékenység elvégzésének, a munkavégzésnek a képességét jelöli. A munkavégzés képessége és a munka vállalásának képessége nem azonos fogalmak. Utóbbi körbe azok a képességek tartoznak, amelyek a munkavégzésre irányuló jogviszony létesítéséhez, azaz a szerződés, a megállapodás tartalmának, a munkaadó utasításainak az értelmezéséhez, a belátási képességhez tartoznak. A komplex rehabilitáció szempontjából a kétféle képességcsoport megkülönböztetésének azért van jelentősége, mert vannak olyan, elsősorban értelmileg akadályozott, autista, pszicho- szociális fogyatékossággal élö, vagy súlyosan és halmozottan sérült emberek, akik képesek a munka elvégzésére, de támogatásra van szükségük a munka vállalása tekintetében. Fontos tehát szem előtt tartani az egyéni kompetenciákat és képességeket, a munkavállalás tekintetében. Hiszen attól, hogy egy csoport tagjai pl. mind megváltozott munkaképességüek, még teljesen más és más munkafolyamatok elvégzésére képesek, illetve mások az erősségeik, gyengeségeik. (http 1)

A fogyatékosság, megváltozott munkaképesség állapotának milyensége és mértéke nagyban meghatározza a későbbi életminőség jellegzetességeit. A társadalmi státuszt, a munkaerö- piacon betöltött szerepet. Azonban egy adott csoport tagjait nem szabad homogén egészként, ugyanolyan tulajdonságokkal rendelkező személyekként kezelni. Hiszen minden személy egyéni kompetenciái határozzák meg későbbi munkában betöltött szerepét. Más lehetőségekkel rendelkezik, egy értelemileg sérült, mint egy testileg sérült ember, mégis mindkettőt megváltozott munkaképességü személynek nevezzük. 


\section{Mit tudunk a fogyatékossággal élö emberekről számokban?}

„Becslések szerint több mint 1 milliárd ember él valamilyen fajta fogyatékossággal a világon, ez körülbelül 15\%-a a bolygó lakosságának (a Föld lakosságának 2010-es becslése szerint). Ezek a számok magasabbak, mint a WHO korábbi becslései, amelyeket az 1970-es években végeztek és egy 10\% környéki számot feltételeztek.

A Világ Egészségügyi Felmérés adatai szerint nagyjából 785 millió ember $(15,6 \%)$ a 15 év és az a fölötti népesség tagjai közül fogyatékos, míg a Betegségek Megterhelő Hatásáról készült egész világot vizsgáló felmérés szerint e szám körülbelül 975 millióra tehető (19,4\%). Ebből a populációból a Világ Egészségügyi Felmérés becslései szerint 110 millió ember $(2,2 \%)$ küzd nagyon komoly funkcionális-életviteli problémákkal, míg a Betegségek Megterhelő Hatásáról készített felmérés szerint nagyjából 190 millió ember (3,8\%) rendelkezik „súlyos fogyatékossággal" - ez a megfelelöje olyan fogyatékosságoknak, amely quadriplégiához, súlyos depresszióhoz vagy vaksághoz társulhat. Csak a Betegségek Megterhelö Hatásáról készült felmérés méri a gyermekkori fogyatékosságot (0-14 éves korcsoport); az érintettek számát 95 millió főre teszi $(5,1 \%)$, amelyből 13 millió $(0,7 \%)$ rendelkezik „súlyos fogyatékossággal” (LAKIEGRESSY, 2011:53).

A fogyatékosság, megváltozott munkaképességüvé válás témakörében nagyon fontos és sarkalatos pont a rehabilitáció kérdése, hiszen ahhoz, hogy ezek a személyek kellőképpen vissza vagy be tudjanak illeszkedni a társadalomba, fontos minden létező segítséget megkapniuk a számukra legoptimálisabb állapot eléréséhez, amennyiben ez nem történik meg, még nagyobb hátránnyal indulnak el a nyílt munkaerőpiacon való elhelyezkedésben, illetve a társadalmi integráció útján.

A rehabilitáció fogalmának értelmezésénél fontos lépés, hogy pontosan definiáljuk kik is azok, akik rászorulnak? Kik vannak peremhelyzetben? Egyáltalán, mi is az a peremhelyzet? Számomra ezek a rehabilitáció kulcskérdései, meg kell határoznunk a rászorulók körét, illetve azt a jogi és egészségpolitikai szemszöget, mely alapján rehabilitációra szorultnak ítélünk meg egy réteget. Ez nem könnyü, hiszen az emberiség nagy hányadát érintő rehabilitációval kapcsolatos szemléletek, tendenciák megvalósítása és a megvalósítás módszere nagyban függ és változik az adott kultúra felfogásától, adottságaitól, politikai és vallási nézeteitől. A rehabilitáció egy-egy adott állam fejlődésének, szociális érzékenységének indikátora. 
Ahhoz, hogy a rehabilitáció társadalmi folyamatát megismerjük, elöször két alapvető fontosságú folyamatot kell megismernünk. Az egyik az életminőség, a másik ennek a leromlása.

Életminőség

Ha közelebbről vizsgáljuk az életminőség összetevőit, azokat az alábbi szempontok alapján csoportosíthatjuk.

-Vannak az életminőségnek abszolút tényezői:

- Jövedelem, vagyon,

- lakás, lakáskörülmények,

- családi állapot, gyermekek együtt élők száma,

- kor, korosztály,

- egészségi állapot

- gazdasági aktivitás

E tényezök mellett még a különbözö tevékenységekben való részvétel is meghatározza az egyén jóllétét, életminőségét. (JAVORNÉ et al. 2014). Kevés eltéréssel az életmód vizsgálatoknak is ezek a legfőbb szempontjai. Az életminőség és az életmód viszont épp abban különböznek egymástól, hogy az életmód nagyobb részt fizikai síkon zajló anyagi életvitel. Gyakorlatilag kívülről elemezhető, ezért az egyén és a társadalom életének reális mérésére is alkalmas. Az életminőség több ennél, az emberi élet lényegét jellemző tulajdonságok, külső meghatározók, körülmények, tényezők halmaza. Az életminőség tényezői szoros kapcsolatban állnak egymással, olyan folyamat ez, mely egész életünket meghatározza. Az életminőség különböző tényezőkből összetevődő jelenség, mely mérhetö. (ZAKÁL,2011)

\section{Leromlás}

Az emberek születésüktől kezdődően, életminőségük keretei között élik életüket. Ezt szoktuk „,normális” életvitelnek tekinteni. A későbbiekben bekövetkező hatások, indíttatások, váratlan helyzetek elindíthatnak egy folyamatot, amely a korábbi életállapotból egyeseknél jobb életminőség eléréséhez, másoknál életminőség romláshoz, esetleg rehabilitációhoz, másokra utaltságot kifejező állapothoz vezet. Ez utóbbi a negatív irányú változás a leromlás más néven deprivatio. Megjelenési formáit és lefolyását illetően a leromlás során megkülönböztetünk három típust: 
- $\quad$ előzmény nélküli azonnali,

- $\quad$ időben elhúzódó és

- $\quad$ hosszabb idő alatt kialakuló eseteket.

Az előzmény nélküli azonnali esetek példája a baleset: amikor például egy gyalogost autó gázol el. Ez az esemény a járókelőt egyik percről a másikra teszi kórházi ápolttá, majd rehabilitációra szorulóvá.

Az időben elhúzódó, valójában kialakuló esetekre példa az a személy, aki büncselekmény elkövetésére készül. Elhatározásától a cselekmény végrehajtásáig lezajló életszakasza, amiben fontolgat, mérlegel, felkészül, társakat szervez ahhoz, hogy egy büncselekmény létrejöjjön.

Másoknál azonban a leromlás hosszú idő alatt kialakuló folyamat, mint például a pszichiátriai betegségeknél, a szegénység egy korábbi állapotból történő beállásánál, ha valaki elveszíti az állását és munkanélküli vagy hajléktalan lesz, elválik, stb. (ZAKÁL,2011)

A rehabilitáció folyamatának megértésénél fontos számba vennünk annak szereplöit, akik a következő három csoportot alkotják:

- rászorulók, jogosultak

- $\quad$ a beilleszkedésre felkészítők

- a befogadók csoportját.

\section{Együttélés- integráció - normalizáció}

A fogyatékos emberekkel szembeni negatív elöítélet, ha talán már nem is olyan erősen, de továbbra is jelen lévő müködő mechanizmus a mai magyar társadalomban, sőt talán minden társadalomban. Ezért van akkora jelentősége azoknak a munkahelyeknek, oktatási intézményeknek, szociális intézményeknek, amelyekben az integráció mellett egyre nagyobb szerepet és hangsúlyt kap az inkluzivitás a befogadás. Számos pozitív változás ment végbe a közelmúltban a megváltozott munkaképességü személyek élethelyzetének, javításának érdekében, számos intézet vált akadálymentesítetté, új re integráló képzések jöttek létre specifikusan ennek a rétegnek, és talán mi emberek is elkezdtünk kicsit ,akadály mentesebben" gondolkodni a témában. A helyzet javulását méltán tükrözi, a felsőoktatásban végbemenő változás is, mely kapcsán egyre több fogyatékkal élö hallgató kezd továbbtanulni, mely szándékukat a nekik járó felvételi többletpont rendszer is elösegíteni hivatott. 


\section{Foglalkoztatás, munka}

Az ember életének az egyik legfontosabb eleme a munka, tevékenység mellyel az ember környezetét olyan módon alakítja, hogy szükségleteit kielégítse ${ }^{1}$, önmagát és társait ellássa. A sikeres munkavégzés feltétele, hogy az azt végző személy birtokában legyen mindazoknak a szellemi és fizikai képességeknek, amelyek szükségesek számára az adott cselekvés sikeres elvégzéséhez. Az értelmi vagy testi akadályozottsággal élő emberek, a munkavállalás, munkavégzés terén is korlátozott lehetőségekkel rendelkeznek. Mégis életük meghatározó részévé, kardinális kérdésévé vált a megfelelni akarás a munka világában. A hasznosság érzésének megtapasztalása. Talán egyfajta társadalmi elvárásként is megfogalmazódott feléjük az igény valamiféle szerepvállalásra a társadalom hasznos tagjaként. Érdekesség, hogy Magyarországon az értelmi fogyatékosok első intézete is a „Munka” nevet viselte a XIX. században.

Ma a hazánkban élő fogyatékos vagy megváltozott munkaképességü emberek közül csak elenyésző százalék rendelkezik a nyílt munkaerőpiacon betöltött állással. Aki rendelkezik is munkahellyel az javarészt csak állami támogatással müködtethető szegregált munkahelyeken lát el védett munkakört.

Egy szociológiai felmérésben a megkérdezett értelmileg akadályozott fiatal emberek (középsúlyos és súlyosan értelmi fogyatékosok) csak mintegy harmada volt hivatalosan is munkavégző $(28,8 \%)$. A napi munkatevékenységekről, házimunkáról 60\%-uk nyilatkozott. „, A háztartás sokak számára nem csak a hasznos tevékenységek körét, hanem a napi elfoglaltságot és az önbecsülést megalapozó értékes munkavégzést is megteremti”, írta a kutató. Mindezt olyan feltételek között végzik, hogy többségüknek nincs a munka formális világában érvényesíthető képzettsége, nem rendelkezik szakmával vagy egyéb iskolai végzettséggel. Magyarországon ez azt jelenti, hogy az értelmileg akadályozottak között csak kb. egy tized rendelkezik szakképzettséggel, ezen belül szakmunkás vagy egyszerü fizikai munkakörökben csupán 4\%-uk tevékenykedik. (HATOS,2000)

A betegségböl, balesetből, esetleg születési rendellenességből származó testi fogyatékosság is komoly oka lehet a peremterületre kerülésnek, a kiszorulásnak a nyílt munkaerőpiacról. Hiába nincsenek ugyanis kognitív, értelmi problémái az

\footnotetext{
${ }^{1}$ A szükségletek kielégítésének egyik eszköze lehet a pénz. Nem hiába írja Giddens (1995), hogy a munka számos fontos dolgot jelent az egyén számára, de elsősorban pénzt. Korábbi kutatások egyértelműen bizonyítják, hogy a munkavállalás motivációi közül a megkérdezettek igen nagyra értékelik és a rangsorban általában első helyre sorolják a fizetést. Erre az eredményre jutott R. Fedor (2015a), a nők munkaerö-piaci integrációja, valamint a R. Fedor (2016) és R. Fedor-Markos (2016) a fiatalok munkaerö-piaci elvárási témában végzett vizsgálata során.
} 
egyénnek, egy munkáltató szemszögéből nézve mégis megváltozott munkaképességü a kifejezés klasszikus értelmében. Hiszen egy ilyen személy foglalkoztatásához javarészt szükség van akadálymentesített környezetre, számukra megfelelő és elvégezhető munkakörre, némi megértésre és empátiára. Számos esetben történik meg emiatt, hogy a megváltozott munkaképességü vagy fogyatékos személy egy egész élethosszig tartó időszakra eltünik a munkaerőpiacról.

Ha a fogyatékosságot, megváltozott munkaképességet emberjogi, társadalmi kérdésként kezeljük, akkor azonnal változik a helyzet, ha nem az egyének és csoportok fizikai, szellemi korlátaira helyezzük a hangsúlyt, hanem arra, hogy az általunk kialakított fizikai és társadalmi környezet hogyan befolyásolja ezeknek az embereknek az életét. Ebben a megvilágításban a társadalom és nem a fogyatékos emberek viselik a beilleszkedés felelősségének súlyát.

A csökkent munkaképesség tehát meghatározó tényezőként behatárolja az értelmileg sérült személyek munkavállalásának lehetőségét a javarészt fizikai munkák területére. A fizikai munkavégzés területein belül is a kognitív károsodás és a személyiség sérüléseinek mértéke határozza meg azt a területet, ahol a személy helyt tud majd állni és elhelyezkedhet. Ez az állapot tehát teljességgel kihat a megváltozott munkaképességü személyek életére. Hiszen állapotuk miatt javarészt kiszorulnak a nyílt munkaerőpiacról, és csak nagyon nehezen találnak maguknak munkát.

\section{Áttekintés, a megváltozott munkaképességü személyek nyílt munkaerő- piaci helyzetéről}

Napjainkban a megváltozott munkaképességü, tartós betegséggel együtt élő és fogyatékos személyek foglalkoztatása már-már mondhatni tradicionális módon elkülönített, speciális paraméterekkel rendelkező munkahelyeken történik. Bár az ilyen szervezetek neve, jogi formája a rendszerváltás óta többször módosult, átalakult, a szervezetek jellegében nem történt jelentős változás.

A megváltozott munkaképességü személyeket foglalkoztató cégek, vállalatok valamennyire mindig különböznek az ilyen munkaerőt nem alkalmazó társainktól, hiszen lényeges állami támogatás, egyfajta dotáció áll mögöttük, gondoljunk itt az adókedvezményekre, vagy csak arra a szinte feltétel nélküli társadalmi elfogadásra, mely nagyban megkönnyíti müködésüket. Hiszen mindenki számára elkönyvelt tény, mondhatni teljes társadalmi axióma, hogy ha megváltozott munkaképességű személyről van szó, akkor az ő helye egy ilyen védett speciális munkakörnyezetben van. 
Azonban a jelenünket érintő változások egyre inkább rámutatnak azokra a tényezőkre, melyek nem csupán ezt az utat hirdetik: más nagyobb „integrációval” járó lehetőségeket kutatnak. Teljesen egyértelmü azonban, hogy ezeket a változásokat nem olyan egyszerú véghezvinni, hiszen az évtizedek óta bevált úton, vagyis a védett foglalkoztatáson nem is olyan könnyü változtatni. Az egyre inkább növekvő igény a pénzbeli támogatásokra, és egyéb szubvenciókra azt mutatja, hogy ez nem csupán a megváltozott munkaképességủ fogyatékossággal élő emberek fizikai állapot romlásának köszönhető, sokkal inkább a munkaerő-piaci kiszorító mechanizmusoknak tudható be. Erre a folyamatra a speciális munkakörök, munkahelyek számának emelkedése sem jelent teljességgel megoldást.

Ez a felismerés egyetlen lehetséges úthoz, megoldáshoz vezethet, mely a megváltozott munkaképességü személyek nagyobb arányú elhelyezkedését hivatott megteremteni a nyílt munkaerőpiacon. A megváltozott munkaképességü emberek foglalkoztatási problémáinak felismerése után mind nemzetközi, mind hazai célkitüzéssé vált a helyzet javítása, különböző programok, képzések és munkahelyek teremtésének eszközével. Hiszen számos esetben jelent az problémát, hogy bár a megváltozott munkaképességü ember nagyon szeretne elhelyezkedni a nyílt munkaerőpiacon, mivel azonban éveket töltött a védett foglalkoztatásban, nem rendelkezik a piaci viszonyokhoz szükséges kompetenciákkal, illetve lelkileg sem elég felkészült egy teljesen új élethelyzet megéléséhez. Ezen tényezők figyelembevételével egyértelművé válik tehát a reintegrációs képzések szükségessége, melyek mind tudásban mind lelkileg felkészítik ezeket az embereket az új körülmények és helyzetek elfogadására.

Optimális esetben az olyan munkalehetőségek lennének a legmegfelelőbbek a megváltozott munkaképességü személyek számára, mely területeken éles a piaci verseny így szükség van az ilyen feladatokat betöltő munkaerőre, szükség van az elöállított termékre. Azonban a realitások sajnos nem ilyen helyzetet tükröznek: sokkal inkább olyan munkahelyek elérhetőek számukra, melyek nem igényelnek túl nagy képzettséget, sem magas értékủ tőkebefektetést. Javarészt tehát olyan munkák betöltéséről beszélhetünk, melyeknek alacsony a bérköltsége.

A fejlettebb európai, nyugati kultúrákban sokkal korábban megszületett az igény az ilyen fajta átalakulásra. Egészen pontosan már az ötvenes években megkezdődött és a hatvanas évekre le is zárult a paradigmaváltás. Szemléletüket tekintve áttértek az úgynevezett ,supported employment” azaz támogatott foglalkoztatás politikájára. Mely annyit jelent, hogy nem csupán a védett munkahelyeket támogatják első sorban, hanem bármely „,normál” munkahelyet is mely foglalkoztat megváltozott munkaképességü munkavállalót.

Napjainkban sajnos egyre gyakrabban találkozni azzal a mechanizmussal, amikor egy megváltozott munkaképességü ember azonosul a „szerepével” elfogadja azt, nem csak önmaga, de a társadalom által is, mely szerep egy alacsony megbecsültséget hordozó alacsony társadalmi elfogadottságot jelentő státuszt 
reprezentál. Azon elgondolkodva, hogy hogyan is tudnánk megváltoztatni a már kialakult helyzetet, az első lépés talán az kellene hogy legyen, hogy magukat a szerepeket változtatjuk meg és ruházzuk fel teljesen más tulajdonságokkal. Nyilván ezt véghezvinni nem egyszerü, és még ha sikerül is, sem megy egyik napról a másikra. Azonban paradigmaváltás segítségével mégiscsak elérhetőbbé válik egy jobb, pozitívabb állapot.

Melyek is azok a tényezők, melyek segíthetnek ebben?

Az első és legfontosabb maga a képzés. Képzés alatt pedig nem csupán a már kialakult tünet, a munkanélküliség kezelésére gondolok, hanem arra, hogy megelőzzük ezt az állapotot. Minél több megváltozott munkaképességü személynek legyen lehetősége bekerülni a felsőoktatásba, szerezzen versenyképes szakmát, kapjon lehetőséget arra, hogy bővítse tudástárát.

Amennyiben azonban a „leszázalékolás”, rokkanttá válás előtt nem állt módjában olyan ismereteket, tudást megszerezni mely később elengedhetetlen lenne egy versenyképes állás megszerzéséhez olyan képzésekre lenne szükség mely a már kialakult szegregált helyzetükön hivatott valamilyen módon segíteni.

Mivel azonban a halmozottan hátrányos helyzetben lévő csoportok teljesen más problémákkal küzdenek, mint a „,normál” munkavállalók, véleményem szerint a nekik szánt képzést is speciális struktúra alapján kell felépíteni. Trénerként szerzett tapasztalataim alapján, azt mondhatom, nagyon nagy hangsúlyt kell fektetni a kölcsönös bizalom kialakítására, és arra, hogy az évek óta védett környezetben élő és dolgozó vagy csak munkát nem találó emberek zárkózottságát, társadalmi elidegenedését valamilyen módon oldani tudjuk. Egy ilyen képzés során nem a tudásanyag átadása a legnehezebb feladat, hanem annak a légkörnek a kialakítása, melyben átadható ez a tudásanyag.

A következő sarkalatos pont a nyílt munkaerö-piaci rugalmasság, mely elengedhetetlen a megváltozott munkaképességü személyek elhelyezkedéséhez. Fontos lenne arra specializálódott vállalkozások létrehozása, melyek az olyan a piaci lehetőségek kínálta réseket hivatottak feltérképezni, ahol a megváltozott munkaképességü dolgozók lennének megfelelőek egy-egy adott munkakör betöltésére, vagy feladat elvégzésére pl.: távmunkák, informatikai feladatok, tele marketing stb.

Nagyobb hangsúlyt kellene fektetni arra, hogy ezek a lehetőségek eljussanak ahhoz a célközönséghez, akiknek szólnak pl.: specifikus állásbörzék, illetve specifikus munkaközvetítő cégek segítségével.

A vállalatok és cégek nagyobb arányban kellene, hogy részt vegyenek a társadalmi felelösségvállalásban.

Olyan vállalati szemlélet, stratégia elmélyítésére lenne szükség, mely alkalmazásával nőne az olyan emberek alkalmazási hajlandósága, akik valamilyen társadalmi hátrányt szenvednek el, pl.: megváltozott munkaképességü emberek, 
romák, nők stb. bármely olyan csoport, akik valami miatt hátrányos megkülönböztetésben részesülnek.

Amennyiben a helyzetet mérlegelve úgy véljük, hogy pozitív elörelépés lenne a megváltozott munkaképességü emberek nyílt munkaerő-piaci elhelyezkedése, úgy a jogi formától, szabályozástól eltekintve minden olyan szervezetnek meg kellene kapnia azt az állami dotációt, szubvenciót, amely segítségével könnyebben tudnak hátrányos helyzetben lévő embereket foglalkoztatni. Ennek a folyamatnak igazzá kell válnia a munkaerő-piaci kirekesztést átélő rétegre is. Tehát, bármilyen típusú munkakört szeretne is betölteni egy megváltozott munkaképességü személy, ott ne fogyatékosságának típusából adódó beskatulyázás legyen a döntő tényező, hanem személyes kompetenciái és saját akarata. A megváltozott munkaképességü személyek által igénybe vehető szolgáltatások, képzések kiválasztásánál sem az legyen a szempont, hogy állapotából adódóan vajon mire nem lehet képes egy ilyen ember, hanem az, hogy állapotához képest mennyi mindenre képes mégis egy ilyen személy. A döntések és választások váljanak a megváltozott munkaképességü személyek saját preferenciájává. (http 2)

\section{A TÁMOP-5.3.8.A3-13/1-2013-0020 azonosító számú projekt bemutatása, célja és alapelvei:}

A pályázat célja a megváltozott munkaképességü, foglalkozási rehabilitációban részesülő személyek munkaerő-piaci integrációjának elősegítése, javítása képzésekkel, szakmai és informatikai fejlesztésekkel, munkaerő-piaci szolgáltatások biztosításával. Jelenleg a foglalkozási rehabilitációra szakosodott szervezetekben foglalkoztatott megváltozott munkaképességü személyek nehezen tranzitálhatók, és általában bennragadnak a támogatott foglalkoztatás rendszerében akár több évtizedre is.

Ugyanakkor e szervezeteknek kiemelt jelentősége van a megváltozott munkaképességű személyek védett környezetben történő foglalkoztatása területén, illetve a nyílt munkaerő-piacon történő foglalkoztatásának elősegítésében. A megváltozott munkaképességü személyek tranzit foglalkoztatásának hatékonysága, növelése érdekében speciális kompetencia- és készségfelmérésekre, fejlesztésekre, valamint képzésekre van szükség. A megvalósuló fejlesztéseknek köszönhetően egyszerre valósul meg a célcsoport tagjainak hatékony felmérése és képzése, valamint lehetőségük nyílik lakóhelyükhöz közel hatékony, komplex munkaerő-piaci szolgáltatások igénybevételére, ezáltal az elhelyezkedési esélyeik jelentősen javulnak. Jelen konstrukció célkitüzései egybe esnek az Európa 2020 Stratégia célkitüzéseivel, melyek az intelligens, fenntartható és inkluzív 
növekedés a magas foglalkoztatottság, a készségek fejlesztésébe való beruházás, a szegénység leküzdése és a munkaerőpiac modernizálása.

A képzési rendszerek révén az emberek képessé válnak az előttük álló változások felmérésére, a változások kezelésére és összetartóbb társadalom kialakítására. A pályázati kírás hozzájárul a Társadalmi Operatív Programban megfogalmazott munkaerő-piaci hátrányok újratermelődésének megakadályozáshoz és önálló jövedelemszerzésre való képesség javításához.

A hazai fejlesztési terveknek is célja a jelenleg inaktív, munkaképes korú lakosság azon tagjainak integrálása - tranzit foglalkoztatás erősítése által is - a munkaerőpiacra, akik megmaradt munkaképességük alapján képesek munkát végezni, s részükre biztosítható is munkahely. Ezen cél eléréséhez elengedhetetlenül szükséges a megváltozott munkaképességü emberek foglalkoztatási arányának növelése, amely jelenleg az EU-ban 50\%, Magyarországon pedig 23\%. 2008-ban Magyarországon a magánháztartásokban élő tartós betegséget, egészségkárosodást vagy fogyatékot jelző mintegy 1,748 millió 18-64 éves (793 ezer férfi és 955 ezer nő) 53,7\%-a válaszolt igennel arra a kérdésre, hogy a munkavállalásban, illetve a munkavégzésben egészségi állapota miatt akadályozva érzie magát. Ez az összességében 938 ezer fö - 432 ezer férfi és 506 ezer nő - tekinthető megváltozott munkaképességünek, hiszen ők azok, akiknek a munkaeröpiaci szerepvállalását egészségi állapotuk megakadályozza, illetve valamilyen mértékben nehezíti.

A népszámlálási adatok szerint a megváltozott munkaképességüek a munkaerőpiacon erősen alulreprezentáltak. Az aktivitási arány 27,4\%-ot ért el, amíg a változatlan munkaképességüeknél 72,7\%-ot. A foglalkoztatási rátájuk pedig $23 \%$ a megváltozott munkaképességüek esetében és $67,3 \%$ a változatlan munkaképességüeknél. A fogyatékossággal élők körében az alacsonyabb foglalkoztatottság miatt a szegények aránya 70\%-kal nagyobb az átlagosnál. A fogyatékos emberek körében hazánkban még mindig átlag alatti az iskolázottsági szint, az alapfokú végzettséget sem sikerül megszerezni 29\%-nak.

A megváltozott munkaképességü munkavállalók nyílt munkaerőpiacon történő elhelyezkedési esélyei rendkívül csekélyek, és jelenleg nehezen jutnak hozzá olyan, az elhelyezkedést elősegítő munkaerő-piaci szolgáltatáshoz, mely hatékony, a fejlesztéseket és a munkaerő-piaci elhelyezkedést segíti elő. A 2011. évi CXCI. törvény a „A megváltozott munkaképességü személyek ellátásairól és egyes törvények módosításáról" hatására várhatóan több megváltozott munkaképességü személy munkaerő-piaci szolgáltatáshoz való hozzáférését kell biztosítani. A TÁMOP-5.3.8 konstrukció céljait egy kiemelt (TÁMOP-5.3.8-11/A1) és kétpályázatos komponens keretében kívánja elérni. A TÁMOP-5.3.8-11/A1 kiemelt program keretében egy Országos szakmai és módszertani központ kerül létrehozásra, mely szakmai, módszertani, informatikai hátteret, szolgáltatásokat, szakmai támogatást biztosít a kiemelt programhoz szorosan illeszkedő TÁMOP- 
5.3.8.A2-es és a TÁMOP-5.3.8.A3-as konstrukció kedvezményezetteiből létrejövő munkaerö-piaci szolgáltató és szakmai támogató hálózat tagjai számára.

A munkaerő-piaci szolgáltató és szakmai támogató hálózat tagjai egyfelől a megváltozott munkaképességü személyek elhelyezkedését segítő szolgáltatásokat nyújtanak, másfelöl a védett foglalkoztatók által foglalkoztatottak tranzitálásával kapcsolatos tevékenységekhez járulnak hozzá, és segítik ezzel elő a nyílt munkaerö-piaci integrációt. (http 3)

\section{A képzés fő irányelvei a következők}

A védett szervezetek a megváltozott munkaképességú munkavállalók nyílt munkaerőpiacra történő visszavezetésének megvalósításának érdekében, alapozó mentális és képesség fejlesztő majd ehhez kapcsolódó szakmai képzések lebonyolítását végzik a TÁMOP 5.3.8. projekt keretében. A képzés kifejezetten rehabilitációs alapokon nyugvó, a munkavállalást elösegítő, elméleti, valamint egyéni és kis csoportos interaktív érzékenyítő (gyakorlat) elemeket tartalmazó rendszerben lett felépítve. A képzés elősegíti a résztvevők személyiségének fejlesztését, stressz-és konfliktus- kezelését, a reális önértékelés kialakítását. Megtanítja őket a csoportos munkavégzés törvényszerüségeire, előnyeire, nehézségeire, érzékennyé teszi őket egymás eltérő tulajdonságaira. Gyakoroltatja és fejleszti a beilleszkedés, az alkalmazkodás és az önálló ügyintézés képességeit, viselkedés-elemeit.

A megváltozott munkaképességü emberek elvesztették önbizalmukat, reménytelennek tartják a munka világába való visszatérést, bejutást, nem bíznak abban, hogy képesek elsajátítani az ismereteket. A munka világában végbemenő folytonos és gyors változások miatt fel kell készülni arra, hogy az egykoron megszerzett szakismeret, tudás, képesítés nem biztosít munkát egy egész élethosszon át.

Fel kell készülni a változásra, az új ismeretek, képességek, kompetenciák elsajátítására és befogadására. Ezen képességek birtokában, - melyek rugalmasabbá teszik a munkavállalókat- felkészülhetnek az új és megváltozott élethelyzetre. Képessé válnak életpálya építésre, önálló életvezetésre és a munka világában is könnyebben tudnak érvényesülni. Ahhoz, hogy a tranzit foglalkoztatás hatékonyságát növeljük, készség és képességfejlesztésekre van szükség. Ezért fontos, hogy a képzés, a pszicho-szociális támogatás keretében olyan szolgáltatást gyújtson a megváltozott munkaképességü személyek számára, amely egyénre szabottan segíti felzárkóztatásukat, identitásukat és önértékelésüket.

Ezen képzéssel a nyílt munkaerő-piaci foglalkoztatási esélyeik javítását célozza meg. A projekt stratégiai célja, hogy a megváltozott munkaképességü 
munkavállalók társadalmi exklúziója megszünjön, önálló jövedelemszerző képességük kialakuljon. A projekt általános célja, hogy fogyatékos és megváltozott munkaképességü emberek a jelenleginél sokkal nagyobb mértékben jussanak munkához, lehetővé váljon számukra is az integrált munkaerőpiac elérése.

A szakmai rehabilitáció szükségességét gyakran csak az emberi és szociális tényezőkkel indokolják, holott a szakmai rehabilitáció ráfordításai megtérülnek, hiszen az abban részesülö személy munkát vállalhat és ennek sokkal nagyobb a társadalmi hozadéka.

\section{Empirikus vizsgálat a megváltozott munkaképes- ségű személyek munkaerő-piaci integrációjáról}

A megváltozott munkaképességü személyek helyzetének feltérképezésére kvalitatív adatgyüjtési módszerrel lebonyolított vizsgálatom fö célkitüzése az volt, hogy feltárjam, hogy milyen pozitív hatásai vannak a már korábban említett pályázat (TÁMOP-5.3.8.A3-13/1-2013-0020) keretében megvalósított képzési tréningnek az érintettekre vonatkozóan. A projektben részt vevők közül 25 föt kérdeztem meg interjús technikával, Szabolcs-Szatmár-Bereg megyében, 2015ben $^{2}$. Azokra a konkrét gyakorlati tapasztalataikra voltam kíváncsi, melyek segítségével úgy érzik, jobban boldogulhatnak a nyílt munkaerőpiacon. Arra kerestem a választ, hogy mivel érzik magukat felkészültebbnek a képzés előtti állapotukhoz képest, illetve a képzésben részt nem vevő társaikhoz képest.

Kutatásom során adataimat kvalitatív, azon belül a félig strukturált mély interjú módszerével gyüjtöttem, ez azért meghatározó, mert témaválasztásom vizsgálata során ezt tartottam a legadekvátabbnak. Olyan információkra voltam kíváncsi ugyanis, amelyek a kérdőívezés során nem biztos, hogy a felszínre kerültek volna, sokkal inkább bizalmasabbnak, közelibbnek éreztem az interjúkészítés lehetőségét.

Elsődleges célom az volt, hogy megpróbáljam mérhetővé tenni a projektben részt vevő emberek szemszögének bemutatásával a tréning pozitív hatásait, bemutatni azokat az elemeket, melyek segítettek ezeknek az embereknek, illetve rámutatni arra a kezdeti kissé negatív állapotra, mely a képzés végére teljesen megváltozott.

\footnotetext{
${ }^{2}$ A megyei, valamint a megyéhez kötődő munkaerő-piaci helyzet értékeléséről bővebben olvashatunk R. Fedor és Balogh (2015), R. Fedor (2015b) írásaiban.
} 


\section{Szociodemográfiai és szociokultúrális mutatók:}

A megkérdezettek átlagéletkora 51 év. A legfiatalabb megkérdezett 29, míg a legidősebb személy 61 éves volt a megkérdezés pillanatában.

A megkérdezett megváltozott munkaképességü személyek közül 15 nő, illetve 10 férfi válaszolt kérdéseimre.

Az általam lekérdezett 25 személy közül kettő rendelkezik diplomával, azaz fejezte be a föiskolát, azonban nyelvvizsga bizonyítvány hiányában nem kapták meg teljes értékü oklevelüket. A további 23 megkérdezett közül 7 személy rendelkezik 8 általánossal, a további 16 fő pedig szakmunkás bizonyítvánnyal. A 25 fő megkérdezett közül 4 személy szerzett valamilyen Okj-s bizonyítványt már meglévő eredményei mellé.

\section{A megváltozott munkaképesség oka:}

Az általam lekérdezett személyek közül sokan rendelkeznek egyszerre több betegséggel is, ezért nem lehetett problémáikat egy-egy okként elkönyvelni, hiszen néhányuk halmozottan, több betegséggel küzd egyszerre. A megváltozott munkaképességhez vezető problémák, betegségek között vezető indok volt az általam lekérdezett személyek között a pszichés megbetegedések aránya. Számomra ez elég meglepő, hiszen benyomásaim alapján az ,átlagember” fogyatékkal élő, megváltozott munkaképességü személy említése kapcsán szinte kivétel nélkül egy tolószékhez kötött, mozgáskorlátozott emberre gondol. Nos, ez esetünkben korántsem alakult így. Az általam feltett „Mi történt Önnel? Milyen betegséggel küzd, mi a problémája?” Kérdésre a következő főbb betegség csoportokat jelölték meg a lekérdezett személyek:

\begin{tabular}{|l|c|}
\hline \multicolumn{1}{|c|}{ Az egészségkárosodások fó csoportjai: } & Az egészségkárosodásban szenvedők: \\
\hline Szív problémák: & 3 fó \\
\hline Daganatos megbetegedés: & 2 fó \\
\hline $\begin{array}{l}\text { Pszichés betegségek (paranoid skizofrénia, } \\
\text { depresszió, pszichózis, neurózis, szorongás, } \\
\text { üldözési mánia/saját megfogalmazásaik } \\
\text { alapján/): }\end{array}$ & 10 fó \\
\hline Vesebetegség: & 1 fó \\
\hline $\begin{array}{l}\text { Látásszervi megbetegedés (szürke hályog, } \\
\text { zöld hályog): }\end{array}$ & 2 fó \\
\hline $\begin{array}{l}\text { Mozgásszervi ízületes megbetegedések } \\
\text { (enyhe vagy teljes mozgáskorlátozottság): }\end{array}$ & 4 fó \\
\hline
\end{tabular}




\begin{tabular}{|l|c|}
\hline Diabétesz: & 1 fö \\
\hline Agyvérzés: & 1 fö \\
\hline Epilepszia: & 1 fö \\
\hline
\end{tabular}

\section{Társadalmi kirekesztettség érzete}

A lekérdezettek közül 14 fö érzi magát a társadalmon belül kirekesztett személyként. nyolc fő úgy véli egyáltalán nincs kirekesztve, három fö pedig titkolja környezete elöl betegségeit, hogy véletlenül se váljon kirekesztetté. Azon személyek közül, akik úgy érzik, hogy kirekesztettként élnek kivétel nélkül mindenki a nyílt munkaerő-piaci státuszában érzi elsődlegesen kirekesztettnek magát. Hiszen az életében előforduló egyéb problémákat, akadályokat „teljes értékü” emberként képes leküzdeni, azonban a munkaerőpiacon mégsem kap lehetőséget a védett szervezeteken kívül.

\section{Elvárások a képzéssel kapcsolatban:}

A tréningen részt vevők közül 12 fő egyáltalán nem örült annak, hogy bekerült egy ilyen képzésbe, félelemmel töltötte el öket a tudat, hogy újra „,vissza kell ülniük az iskolapadba". 8 fö nem tudta mire számítson, vegyes érzelmekkel, izgatottsággal vágott bele a tréningbe, és csupán a részt vevők közül 5 fő fogadta örömmel azt, hogy újra képezheti magát.

\section{A részt vevők érzései, benyomásai a képzés alatt:}

Ahogyan az előző pontból kiderült, a beiskolázott személyek közül 12 fő egyáltalán nem örült a képzésnek, illetve nyolcan nem tudták mire is számítsanak. Mégis a társaság 100\%-a értékelte úgy, hogy nagyon jól érezte magát a képzésben eltöltött idő alatt. Nagyon pozitív visszajelzés számomra, hogy a kezdeti félelmek, és passzivitás ellenére az oktatás zárásánál minden résztvevő úgy nyilatkozott, hogy élmény volt számára ez a tréning és az oktatás teljes folyamata alatt kellemes benyomások érték őket, illetve, hogy minden kezdeti aggodalmuk, idegességük, elszállt. 


\section{Magabiztosabbá váltak-e a résztvevők a képzés során:}

Az általam megkérdezett 25 főből, 25 úgy érezte, hogy fejlődött magabiztosság terén. Nagyon fontos kérdés a megváltozott munkaképességü személyek életében az önbecsülés, magabiztosság, az önmagunkért való kiállás. Hiszen egy „,egészséges" társuk számára is igen fontos tényező például egy állásinterjún való részvétel során. Tapasztalataim alapján épp a magabiztosság volt az, ami alapvetőleg hiányzott ezekből az emberekből, így nagyon nagy elörelépésnek tartom, hogy véleményük, benyomásaik alapján fejlődni tudtak a képzésben való részvételüknek köszönhetően és 100\%-os arányban úgy érezték, előnyükre változtak.

\section{Mely modulegységeket emelné ki, mely egységek adták a leginkább hasznosítható tudást:}

A tréning során a részt vevők húsz modulegység témáit tanulmányozhatták, vehették át. A témakörök mind-mind a személyes fejlödésüket segítették elö. Azonban minden személy kompetenciái eltérőek voltak, ezért arra a kérdésre kerestem a választ, hogy kinek mely terület jelentette a legnagyobb elörelépést, melyik modulegységből profitálta a legtöbbet. A válaszadók a 20 modulegység közül érdekes módon 4 modult preferáltak, illetve találtak hasznosnak a leginkább. Az eloszlás ezek között a következő volt:

\begin{tabular}{|l|l|l|}
\hline \multicolumn{1}{|c|}{ Modulegységek címe: } & $\begin{array}{l}\text { Az azt választó } \\
\text { fök száma: }\end{array}$ \\
\hline 1 . & $\begin{array}{l}\text { Stressz kezelés. Örömök és bosszúságok azonosítása. A } \\
\text { feszültségekkel való személyes megküzdés módszerei- } \\
\text { nek elsajátítása. }\end{array}$ & 4 fö \\
\hline 2. & $\begin{array}{l}\text { A krízishelyzetek lélektani sajátosságai, krízishelyzetek } \\
\text { felismerése és a feloldásuk lehetséges módozatai. A } \\
\text { személyes krízishelyzetek elemzése, a krízisből kivezetö } \\
\text { lehetséges utak megfogalmazása. }\end{array}$ & 4fó \\
\hline 3. Önálló gondolkodás, szabad akarat. Alapvetö állampolgá- \\
$\begin{array}{l}\text { ri jogok ismerete. Állampolgári jogok és kötelességek, } \\
\text { PTK, BTK, szociális törvény, nemzeti alaptörvény meg- } \\
\text { ismertetése. Társadalmi felelösség vállalás fontossága. Ál- }\end{array}$ & \\
\hline
\end{tabular}




\begin{tabular}{|c|c|}
\hline talános ügyintézés szabályai. Közéleti aktivitás keretei. & \\
\hline $\begin{array}{l}\text { 4. munkahely keresés módjainak ismerete. Munkahely- } \\
\text { keresési technikák, közvetítők igénybevétele, a lehető- } \\
\text { ségek mérlegelése, a megfelelő munkahely kiválasztása; } \\
\text { önéletrajz és motivációs levél, a bemutatkozó beszélge- } \\
\text { tés technikái. Formanyomtatványok kitöltése. }\end{array}$ & 10fö \\
\hline
\end{tabular}

A mért adatokból elmondható, hogy a legnagyobb érdeklődést egyértelműen a konkrét munkavállalás elősegítéséhez szükséges információk váltották ki, illetve az alapvetó állampolgári jogokkal és kötelességekkel foglalkozó modul. Továbbá 8 föt, a stressz- helyzetek kezelése, illetve a krízishelyzetek lehetséges megoldása érdekelte leginkább, mely adat nem meglepő, hiszen az interjúk során kiderült, hogy a megkérdezettek legnagyobb arányban lelki problémákkal, gondokkal küzdenek.

\section{A képzés pozitív mentális hatásai:}

A tréningen részt vevő személyeket arról kérdeztem, hogy jelentett-e számukra pozitív lelki változást a képzés az azt megelőző állapotukhoz képest, és amenynyiben igen az miben nyilvánul meg. A 25 válaszadóból 24 személyt ért pozitív változás, egy fő azonban úgy érzi, hogy nem tapasztalt változást állapotában.

\section{Csoportos munkavégzés a képzés után:}

A tréning indításánál, meglepetten tapasztaltam, hogy csoportjaim tagjai nem szívesen beszélgetnek egymással, illetve, hogy nem szívesen vesznek részt csoportos feladatok megoldásában. Az első időszakban talán még egymás köszöntése is elég nehézkesen zajlott, számtalan esetben jelentett problémát pl. egy közös feladat megoldásánál, hogy nem szerettek volna egymás előtt problémáikról beszélni. Természetesen ez az állapot rengeteget változott az idő előre haladásával, azonban kíváncsivá tett, szerettem volna meghallgatni a tagok saját véleményét is arról, hogy szerintük változott-e hozzáállásuk, a továbbiakban fog-e számukra gondot jelenteni a csoportos munkavégzés, vagy az idegenekkel való megismerkedés pl. egy új munkahely keretei között. A válaszadók 100\%-a egybehangzóan úgy érzi, hogy a képzés segítségével sokkal inkább nyitottabb, elfogadóbb lett, ezáltal a jövőben sokkal jobban tud majd csoportban dolgozni. 


\section{Több készséggel rendelkeznek-e a nyílt munka- erőpiacon való sikeres elhelyezkedéshez a kép- zésben részt vett személyek, mint az abból kima- radt társaik?}

Számomra ez a kérdés volt szakmailag a leginkább fontos, ám ahogy belemélyedtem a témába és elkészítettem az interjúimat a képzésben részt vett személyekkel, rá kellett jönnöm, hogy ez a kérdés is csak az egész apró része. Minden egyes pozitív előrelépés, minden egyes jó tapasztalat, vagy újdonság, ami ezeket az embereket érte sokat segített nekik, hogy nagyobb eséllyel indulhassanak el munkakeresés útján. Mégis talán az erre a kérdésre adott válaszuk teszi leginkább kézzel foghatóvá a képzésben elért eredményeket. A 25 válaszadó személyböl 24 úgy gondolja, hogy a képzésnek köszönhetően nagyobb esélye van elhelyezkedni a nyílt munkaerőpiacon, mint az abból kimaradt társainak, véleményük szerint számos olyan készséggel gazdagodtak, melyeknek előtte nem voltak birtokában.

\section{Utánkövetés:}

A pályázat lezárása után, az abban részt vevő személyek utánkövetése során adatfelvétel történik életük aktuális helyzetéről, a munkaerőpiacon beötlött státuszukról, illetve aktuális egészségügyi állapotukról. A tréning időtartama 2015 januárjától 2015 májusáig tartott. Az utánkövetési lekérdezések a tréning befejezése után, három hónappal kezdődtek el, majd ismétlődtek meg ez év januárjában. A lekérdezett adatokból a következők információk derültek ki:

\begin{tabular}{|c|c|}
\hline $\begin{array}{l}\text { A képzésben részt vett személyek aktuális } \\
\text { állapota: }\end{array}$ & A lekérdezett személyek száma: \\
\hline $\begin{array}{l}\text { A képzés elvégzése után az egészségügyi } \\
\text { felülvizsgálat alkalmával egészséges stá- } \\
\text { tuszba került, tehát elvesztette megváltozott } \\
\text { munkaképességű státuszát: }\end{array}$ & 5 fó \\
\hline A képzés befejezése után, életét vesztette: & 1 fö \\
\hline A képzés után munkanélküli maradt: & 4 fö \\
\hline $\begin{array}{l}\text { A képzés befejezése után védett munkahe- } \\
\text { lyen állást szerzett: }\end{array}$ & 8 fö \\
\hline $\begin{array}{l}\text { A képzés bejezése után nyílt munkaerö- } \\
\text { piaci állást szerzett: }\end{array}$ & 7 fö \\
\hline
\end{tabular}


A tréning kezdő pontjának lekérdezéséből kiderült, hogy a pályázat előtt csupán 11 fö dolgozott valamilyen nyílt vagy védett munkahelyen a többi részt vevő munkanélküli státuszban volt. A tréning elvégzése után ez a szám a lekérdezett adatok alapján 15 főre emelkedett. Illetve az 5 fö egészséges státuszba került személy közül további 2 fónek sikerült elhelyezkednie a munkaeröpiacon. Tehát az állást szerzett személyek száma az azt megelőző 11 föhöz képest összesen 17 lett.

Az interjúk elemzése során, arra a következtetésre jutottam, hogy bár kutatásom témája, a nyílt munkaerőpiacon való elhelyezkedéshez szükséges kompetenciák fejlődését szerette volna mérhetővé tenni, mégis az interjúkérdésekre kapott válaszok alapján úgy gondolom a pályázat minden része sikeres volt. Az abban részt vevő emberek, nem csupán képességeik tekintetében fejlődtek, de saját maguk megítélése is megváltozott. Látva a borzasztóan nehézkes kezdeti szakaszt, a képzésnek köszönhetően mégis az általam lekérdezett 25 föből 24 távozott úgy, hogy alkalmasabbnak érezte magát a nyílt munkaerő-piaci elhelyezkedésre, magabiztosabbá nyíltabbá váltak.

A képzés sikere nem csupán abban mérhető, hogy hány fő fog később elhelyezkedni, hanem abban is, hogy sikerült kizökkentenünk ezeket az emberek a sok éve megszokott rutinjukból, zárkózottságból. Az átadott modulokon, kívül számos olyan bizalmi játék, csoportos feladat, kézmüves tevékenység (rajzolás, hajtogatás, ragasztás, festés) került bele a tananyagok témájába mely segítette a részt vevők mentális fejlődését.

\section{Összegzés:}

Az általam mért adatok alapján az elsődlegesen megfogalmazott feltevésem, miszerint a TÁMOP-5.3.8. A3-13/1-2013-0020 képzésben részt vett személyek nagyobb eséllyel indulnak a nyílt munkaerőpiacon, mint a képzés elött, az interjúzás során megszerzett adatok alapján beigazolódott. A mért adatok alapján az általam lekérdezett 25 személyből a tréning elött mindösszesen 11 fö rendelkezett valamilyen állással, azonban ez a szám képzés utáni időszakban 17 fơre emelkedett. A képzésben részt vevők magabiztosabbá, határozottabbá váltak. A pályázat megváltozott munkaképességü személyekre gyakorolt pozitív hatása azonban nem csupán ezekben a számszakilag mérhető adatokban rejlik.

Ahogyan az interjúkérdésekre kapott válaszokból kitünik, minden modulegység megélése, minden a tréningben töltött nap egyéni győzelmekkel és sikerélményekkel gazdagította a résztvevőket. Kezdeti, induló, inkább negatív tapasztalataim a tréning végére teljesen átváltoztak. Amikor ezek a személyek bekerültek ebbe a pályázatba, tehát újra visszaülhettek az iskolapadba szinte egytől-egyig 
kétségekkel teli, visszahúzódó, nyilvánosan megszólalni alig merő emberek voltak. Trénerként nem az jelentette számomra a nehézséget, hogy miként tudnám öket fegyelmezni, vagy miként tudnám lekötni figyelmüket, hanem az, hogy a számukra idegen emberekkel egy csapatot alkotva, kialakuljon közöttük valamiféle csoportos kohézió, illetve egy bizalmi légkör. Számos, a képzésbe került személy értékelte magát alul, illetve érezte magát a társadalmon kívül állónak. Az igazán nehéz feladat az volt, hogy önmaguktól ismerjék fel ennek ellenkezőjét. A húsz modulegység során, számos olyan elfeledett készségük és kompetenciájuk került felszínre, melyeknek meglétében már ők sem voltak egészen biztosak.

A tréning kezdeti időszakában tehát januártól kb. egészen február közepéig a csoporttagok számára az okozta a legnagyobb problémát, hogy nem mertek sem előttem sem csoporttársaik előtt hangosan megszólalni, feladatotokat megoldani. A kezdeti feszültségek oldódása után, minden egyes tag elkezdett kinyílni és szárnyalni. Mindenki önmaga felismerése és társai pozitív megerősítése alapján jött rá arra, hogy miben kiemelkedően ügyes vagy mik lehetnek a hiányosságai. Ezek az emberek sajnos évek óta éltek sikerélmények és új ingerek nélkül. Ez a képzés és az a stabil, pozitív, és őket mindennél előbbre tartó intézményi háttér és szakembergárda, illetve ők maguk részt vevők változtatni tudtak ezen a helyzeten. Kommunikációs képességeik, önbizalmuk, a saját magukról és társaikról formált véleményük, alapvető kompetenciáik mind fejlődésnek indultak.

A tréning során teljesen egyértelművé és kézzel foghatóvá vált az, hogy ezek a személyek miért szorultak ki a nyílt munkaerőpiacról. Felvették ugyanis azt a szerepet, amelyet a „társadalom elvár tőlük”, elmerültek problémáikban, gondjaikban, betegségeikben, továbbá nem részesültek olyan oktatásban mely felkészítené őket a jelenlegi nyílt munkaerőpiacon fennálló versenyhelyzetre. A képzés, melyen részt vettek, felruházta őket az álláskereséshez szükséges tudással. Csak a legfontosabb pontokat kiemelve: megtanulták saját jogaikat és kötelességeiket, megtanulták kezelni életük krízis - és válsághelyzeteit, a stresszhelyzeteket, tanultak az egészség megőrzésről, arról, hogyan jelenjenek meg egy állásinterjún és azt, hogyan viselkedjenek egy ilyen helyzetben, megtanultak önéletrajzot, illetve motivációs levelet írni, fejlődött kézügyességük és megtanulták, hogy fejezzék ki magukat. A képzés segítségével visszakapták az önmagukba vetett hitüket. Az interjúválaszok elemzésénél egyértelmüen kiderült, hogy a válaszadók szinte egybehangzó véleménnyel alátámasztják ezeket a megállapításokat. Természetesen a kezdeti bizonytalanságaiknak is hangot adtak, azonban összességében egytől egyig pozitívan élték meg ezt a képzést és az itt megszerzett tapasztalatokat és tudást.

A tréning során megélt tapasztalatok alapján úgy vélem, hogy a mai munkaerö-piaci illetve társadalmi helyzeten csak úgy lehet változtatni, ha minél több ilyen vagy ehhez hasonló képzésen tudnak részt venni a megváltozott munkaké- 
pességű személyek. Ezek a képzések nem csupán esélyt adnak számukra a nyílt munkaerőpiacon való elhelyezkedéshez, de más emberré is teszik őket. Nyílt, magabiztos személyekké válnak, akik magánéleti problémáikkal is sokkal könynyebben tudnak szembenézni. Az a fajta törődés és figyelem, melyet egy ilyen képzés során kapnak, emlékezteti őket, hogy ők is teljes jogú tagjai a társadalomnak, és ezzel a jogukkal élniük is kell.

A kutatási eredmények alapján, egyértelmủen kijelenthető, hogy ezek a képzések hatalmas jelentőséggel bírnak, és nagyon nagy szükség van rájuk. Ha egy megváltozott munkaképességü személy nyílt munkaerö-piaci állást kap egy ilyen képzés révén, vagy esetleg védett munkakörnyezetben marad, az eredmény mindkét esetben kézzelfogható, hiszen jobban és nagyobb lelkesedéssel fogják ellátni feladatukat az általuk megszerzett tudásnak és kompetenciáknak köszönhetően. Nem utolsó sorban egy ilyen képzés természetesen hosszútávon javít a megváltozott munkaképességü személyek társadalmi megítélésén is. Hiszen bátrabban mernek közeledni idegenekhez, bátrabban dolgoznak együtt csoportban addig számukra idegen emberekkel. Ezek az apró előrelépések pedig oldják a jelenleg őket körülvevő társadalmi feszültségeket, ezzel elősegítve csoportjuk társadalmi integrációját.

A reintegráció kulcsa, legyen az társadalmi vagy munkaerő-piaci, kettős felelősségünk, mind a megváltozott munkaképességü személyeknek mind a társadalom többi tagjának felelőssége az, hogy ez a hátrányos helyzetben élő, perifériára került csoport, hogyan éli meg mindennapjait és hogyan tud a társadalom teljes jogú tagjaként beilleszkedni. Ahogyan az a kutatásból kiderül, van értelme és eredménye az ilyen képzések megalkotásának és véghezvitelének.

A fogyatékos, vagy megváltozott munkaképességủ állapot milyensége, annak foka, illetve mértéke számos dolgot meghatároz az egyén későbbi életében, számos lehetőségtől határolhatja, el vagy épp segítheti hozzá. A legnagyobb hatással természetesen az egészségügyi kockázatokon kívül a munka világában, illetve a társadalomban betöltött szerepére hat egy értelmi vagy testi fogyatékossággal élő személy életére. Számos olyan álláslehetőség vagy élethelyzet adódhat, egy ilyen ember életében, melyben sajnos nem indul akkora eséllyel előzetes képzés vagy felkészítés nélkül, mint egészséges társai. 


\section{Felhasznált irodalom}

1. Csoba Judit (2009): Peremhelyzetű társadalmi csoportok társadalmi és munkaerőpiaci integrációja. Debreceni Egyetemi Kiadó.

2. Giddens, A. (1995): Szociológia. Osiris Kiadó. Budapest.

3. Hatos GY. (2000): Értelmileg akadályozott felnőttek pedagógiai kísérése. Eötvös Lóránd Tudományegyetem Bárczi Gusztáv Gyógypedagógiai Főiskolai Kar, Budapest

4. Jávorné Erdei R., Gyulai A., Rusinné Fedor A., Takács P. (2014): Quality of life and community activities. EUROREGIONAL JOURNAL OF SOCIO-ECONOMIC ANALYSIS 2:(1) pp. 39-45.

5. Laki I.-Egressy G. (2011): Esélyegyenlőségi fogalomtár, Glossary of Terms on Equal Opportunities. Belvedere Meridionale, MTA Szociológiai Kutatóintézet, Budapest.

6. R. Fedor Anita (2105a): Egyensúlyban? - A munkaerő-piaci karriertől a familiarizmusig. Debrecen: Debreceni Egyetemi Kiadó, 2015. 252 p.

7. R. Fedor Anita (2015b): Szabolcs-Szatmár-Bereg megye foglalkoztatási és munkanélküliségi jellemzői. In: Rusinné Fedor Anita, Zakor-Broda Rita (szerk.) Társadalmi-gazdasági stratégiai helyzetértékelés a civil szektor bevonásával. $93 \mathrm{p}$.

8. Nyíregyháza: Szabolcs-Szatmár-Bereg Megyei Önkormányzat, 2015. pp. 9-21.

9. R. Fedor Anita, Markos Valéria (2016): Visions of the Students Regarding the Labour Market. In: Engler, Fedor, Markos (ads.): Vision and Plans of the Young People of Nyíregyháza about their Future. YOUTH IN CENTRAL AND EASTERN EUROPE. SOCIOLOGICAL STUDIES 3:(\&) p. \&. (2016) Kézirat.

10. R. Fedor Anita (2016): Values and Future. In: Engler, Fedor, Markos (ads.): Vision and Plans of the Young People of Nyíregyháza about their Future. YOUTH IN CENTRAL AND EASTERN EUROPE. SOCIOLOGICAL STUDIES 3:(\&) p. \&. (2016) Kézirat.

11. Ruzsics (2014): A személyre szabott költségvetés- a felnőtt értelmileg akadályozott személyek társadalmi integrációjának egy eszköze. Esély, 1. 81-90.

12. Zakál J. (2011): A rehabilitáció elméletének és rendszerének vázlata. Bába Kiadó, Budapest-Szeged 
Internetes hivatkozások:

1. http://igyk.pte.hu/files/tiny_mce/File/ekonyvtar/konyvek/a_komplex_rehabi litacio.pdf

( A komplex rehabilitáció, Farkasné Jakab E. „Horváth P., Mészáros A.,Nagy J.T. , Petróczi F. , Sima F. , Szellő J. : A komplex rehabilitáció; Látogatva: 2016.02.01)

2. https://www.google.hu/url? sa=t\&rct=j\&q=\&esrc=s\&source=web\&cd=2\&c $\mathrm{ad}=\mathrm{rja} \&$ uact $=8 \& \mathrm{ved}=0 \mathrm{CCYQFjAB} \& u r l=\mathrm{http} \% 3 \mathrm{~A} \% 2 \mathrm{~F} \% 2 \mathrm{Fwww}$. munkaes ely.hu\%2Ffiles\%2Fmmth_rev_zt_nyilt_mep_vegleges.pdf\&ei=PsmfVPzqD MGvUZalgJgN\&usg=AFQje $\bar{N} F \bar{M} M \bar{u}$ Pz7pFde8cYS800DUmvTtjkg (Dr. Krémer B.: A megváltozott munkaképességű emberek és a nyílt munkaerőpiac; Látogatva:2016. 01.05.)

3. http://palyazat.gov.hu/download/40552/Palyazati_utmutato_konv.doc (Új Széchenyi Terv, Pályázati útmutató a Társadalmi Megújulás Operatív Program; Látogatva:2016.08.14.)

A szerző:

\section{Botfalusi Klaudia}

Tanácsadó , Projektmenedzser. EuroRaptor Tanácsadó és Pályázatíró Kft.

botfalusi.klaudia@gmail.com 
